\title{
METODE KISAH DALAM AL-QUR'AN DAN SUNNAH DAN URGENSINYA DALAM PENDIDIKAN KARAKTER
}

\author{
Bunyanul Arifin* \\ abunyanul@yahoo.com \\ *Dosen Magister Pendidikan Agama Islam, Universitas Muhammadiyah Tangerang
}

\begin{abstract}

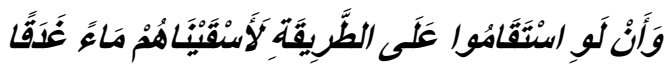

"Dan bahwasanya: Jikalau mereka tetap berjalan Lurus di atas jalan itu (agama Islam),

benar-benar Kami akan memberi minum kepada mereka air yang segar (rezki yang banyak)”.

$$
\text { (Q.S. Al-Jin : 16) }
$$
\end{abstract}

It is undeniable that education is a process that is very important and even most important for humans to achieve the degree of glory in the eyes of Allah SWT and all His creatures. But the education process is not an easy thing, even education is a complex process because it is a planned, systematic, structured effort and aims to develop, manage, foster, direct, and change humans who are multidimensional beings towards perfection. The process of education is the process of "transferring" or transferring knowledge from the source of knowledge contained within explanations and information, the nature of things, and values that are useful for human life. So important is the value of science for humans that the most appropriate way is needed in the transfer process. The Fiqh Rule says, Ma La Yatimmul Obligatory Illa Bihi Fahuwa Obligatory, this means that if Science is very important and compulsory to be studied, then the media that causes that knowledge is acquired is equally important and mandatory. On this basis, education experts formulate strategies and appropriate methods that are in accordance with the basic character and human psyche. Then came the so-called method, uslub or tariqah in education. The method according to the Indonesian dictionary is interpreted as a systematic way of working to facilitate the implementation of an activity in order to achieve the specified goals. And the education method is defined the way or education system used by educators for the success of students to become noble human beings. Among the various methods of Islamic education that are recognized by scholars and education experts as a method of education based on the Qur'an and Sunnah is the Story method. Lots of Qur'anic verses that come down with the form of a story. Similarly, the texts of the hadith of the Prophet Muhammad. This paper will provide an explanation of the story method used in the Qur'an and the Hadith, the value of the educational philosophy contained therein, the power of the story method in moral education, and the urgency of the story method for character education.

Keywords: Story In The Qur'an And Sunnah, Education Character

\section{A. PENDAHULUAN}

Al-Qur'an adalah sumber pertama dan utama bagi umat Islam dalam berbagai aspek dan segi kehidupan. Terlebih lagi dalam masalah pendidikan yang merupakan masalah paling sentral dan sangat menentukan kualitas individu maupun masyarakat. Jika pendidikan dimaknai sebagai jalan untuk mengoptimalkan potensi akal, jiwa dan raga manusia menuju level tertinggi sebagai manusia yang mulia, 
maka bisa kita katakan Al-Qur'an adalah kitab pendidikan dalam pengertian yang sesungguhnya.

Kesempurnaan Al-Qur'an sebagai rujukan utama dalam pendidikan Islam tidak hanya pada aspek-aspek yang mendasar yang berkaitan dengan aspek metafisis dan epistemologis, melainkan juga meliputi halhal yang berkaitan dengan hal teknis mengenai model, sistem, dan metode pendidikan yang tepat dan sesuai dengan fitrah dan potensi manusia.

Diantara metode atau pendekatan pendidikan yang digunakan Al-Qur'an dan kemudian juga dilakukan oleh Nabi Muhamad SAW dalam Sunnahnya adalah metode Kisah. Metode kisah sangat banyak ditemukan dalam Al-Qur'an dan juga Hadits. Bahkan sebuah surat Al-Qur'an ke 28 secara khusus dinamakan dengan nama Al-Qashas (Kisah-kisah).

Kisah-kisah dalam Al-Qur'an juga bukanlah dongeng kosong belaka. Kisahkisah dalam Al-Qur'an memang ditujukan untuk dijadikan ibrah (pelajaran) dan hikmah yang sangat bermanfaat bagi manusia. Karenanya Allah SWT menegaskannya dengan kalimat "sebaikbaik kisah" seperti tertera dalam Al-Qur'an Surat Yusuf : 3 :

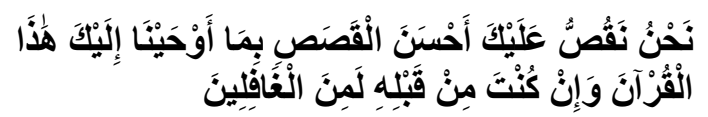

"Kami menceritakan kepadamu kisah yang paling baik dengan mewahyukan Al Quran ini kepadamu, dan Sesungguhnya kamu sebelum (kami mewahyukan) nya adalah Termasuk orang-orang yang belum mengetahui."

Ibn Jarir At-Tahabari dalam tafsir AlKabir menjelaskan bahwa yang dimaksud kisah-kisah terbaik dalam ayat tersebut adalah kisah-kisah yang telah berlalu dari umat terdahulu dan kitab-kitab yang diturunkan pada masa yang terdahulu. ${ }^{1}$

\footnotetext{
${ }^{1}$ Abi Ja'far Muhamad ibn Jarir A-Thabari, Jami alBayan fi Ta'wil Ayil Qur'an, Tahqiq Dr. Abdullah bin Abd al-Muhsin At-Turkiy, Qahirah, Hajar, 2001, Jilid 13, h. 4
}

Kekuatan metode kisah terletak pada kesesuaiannya dengan fitrah manusia. Karena secara psikologis manusia selalu membutuhkan sebuah model atau gambaran ideal dalam hidupnya yang digambarkan dalam bentuk tokoh pahlawan yang jadi contoh untuk diikuti, maupun tokoh antagonis yang harus dijauhi sifat dan karakternya. Dengan anugerah kemampuan otak kanan yang imajinatif dan kontemplatif, sebuah kisah yang bagus dan disampaikan oleh penutur yang baik dalam suasana yang tepat akan memberikan kesan yang mendalam kedalam benak pendengarnya, menghunjam ke dalam kalbu dan melahirkan sebuah kesadaran. Inilah yang disebut dengan internalisasi nilai-nilai yang sebetulnya tujuan utama pengajaran dan pendidikan karakter.

Karena kekuatan inilah maka Muhammad Quthub menyebutnya dengan istilah "kekuatan sihir sebuah kisah". Dalam bukunya Manhaj At-Tarbiyah AlIslamiyah, ia mengatakan :

"Kekuatan sihir dari kisah adalah sesuatu yang sudah sangat tua, setua peradaban manusia, dan kekuatan itu masih dan akan terus ada sepanjang dunia masih ada. Tidak disangsikan lagi, bahwa bagaimanapun juga jiwa pembaca kisah dan pendengarnya -secara sadar ataupun tidakakan hanyut dan terbawa pada pentas peristiwa yang dikisahkan. Imajinasinya membuat dirinya seakan merasakan langsung, kekagumannya pada sosok panutan, maupun penolakannya pada tokoh yang dibencinya, menelusup ke dalam relung jiwanya. Dan Islam mengetahui kekuatan fitrah manusia yang terdapat dalam metode kisah ini, dan menemukan kemampuan kisah dalam menyihir hati manusia, karena itulah ia menjadi salah satu media dan metode pendidikan dan pembentukan jiwa". ${ }^{2}$

\footnotetext{
2 Muhammad Quthub, Manhaj At-Atarbiyah Alislamiyah, Qahirah, Dar Al-Qolam, h. 237, dikutip dalam Dr. Sa'id Ismail Ali, Al-Qur'an Al-Karim ; Ru'yah Tarbawiyah, Qahirah, Dar al-Fikr al-Araby, 2000, h. 310
} 
Hal yang sama kita temukan pula dalam model tarbiyah yang dilakukan Rasulullah SAW kepada para sahabat R.A. Bahkan Rasulullah SAW adalah manusia pertama yang mengikuti metode pendidikan Qur'ani yang diantaranya melalui metode kisah. Dengan cara berkisah inilah seringakali Nabi Muhamad SAW menyampaikan nilainilai kebajikan, kepahlawanan, kedermawanan juga akibat dari perbuatan melawan Allah SWT. Bahkan metode kisah bukan hanya ditujukan kepada kaum muslimin, tetapi juga dihadapan kaum kafir dan ahli kitab yang ingin membuktikan kebenaran Nabi Muhamad SAW. Dengan menceritakan kisah-kisah para Nabi dan umat terdahulu sesuai dengan yang diwahyukan oleh Allah SWT, dan ternyata kisah-kisah tersebut sesuai dengan yang ada dalam kitab suci Ahlul Kitab, menjadi semakin tegaslah kebenaran risalah agama Islam. $^{3}$

Jika Al-Qur'an dan Sunnah menjadikan metode Kisah sebagai media yang efektif sebagai metode dalam pendidikan, maka sudah seharusnya setiap pendidik muslim menjadikannya sebagai salah satu metode dalam pendidikannya. Sedemikian penting dan efektifnya metode kisah dalam pendidikan Islam bisa disimpulkan dari kalimat Abd al-Karim Khatib seperti dikutip oleh Dr. Abdurrahman bin Abd alKhalik Al-Ghamidi , ia mengatakan, "Tidaklah berlebihan jika kami katakan bahwa metode kisah dan jalinan cerita dengan segala imajinasinya adalah kekuatan yang sangat dominan dalam mempengaruhi manusia yang mampu membangkitkan semua potensi kekuatan yang terpendam yang ada padanya".

Namun demikian, alih-alih menjadikan metode kisah sebagai metode internalisasi

\footnotetext{
${ }^{3}$ Dr. Sa'id Ismail Ali, As-Sunah An-Nabawiyah ; Ru'yah Tarbawiyah, Qahirah, Dar al-Fikr Al-Araby, 2002, h. 340.

${ }^{4}$ Abd al-Karim Khatib, Al-Qishah Al-Qur'aniy Fi Mantuqih wa Mafhumih, Qahirah, Dar al-Fikr alAraby, 1974, h. 4, dikutip dalam Dr. Abdurrahman bin Abd al-Khalik bin Hajar Al-Ghamidy, Madkhal Ila At-Tarbiyah Al-Islamiyah, Riyadh, Dar alKhariji, 1418 H, h. 193
}

nilai-nilai karakter kepada siswa, umumnya para guru lebih sering menggunakan metode doktrinasi yang lurus dan kadang menjemukan. Maka wajarlah jika muncul kekhawatiran sebagian kalangan jika 18 karakter yang dijadikan standar pendidikan karakter oleh pemerintah hanya akan menjadi pengulangan model pembelajaran PMP (Pendidikan Moral Pancasila) di masa lalu. Maka anak-anak hanya akan diuji pemahamannya tentang apa itu jujur, disiplin, religius, kreatif, mandiri, tanggung jawab dan lain-lain. Boleh jadi hasilnya anak-anak kita pandai menjelaskan tentang maksud karakter-karakter yang diajarkan, tapi ternyata tidak muncul keinginan kuat untuk mengikuti dan mempraktikannya. Jika keinginan melakukannya saja tidak muncul, maka jauh panggang dari api rasanya jika kita berharap nilai-nilai utama tersebut dapat tumbuh menjadi karakter. Karena karakter, sebagaimana dijelaskan Stephen R. Covey dalam Tujuh Kebiasaan Efektif akan muncul dari kebiasaan, dan kebiasaan akan muncul dari perbuatan yang dilakukan terus menerus. Dan perbutan tentu lahir dari sebuah gagasan dan pikiran.

Pada titik krusial inilah, menanamkan nilai-nilai ke dalam benak pikiran siswa, pendidikan dengan model kisah menemukan nilai urgensinya, selain tentu dibarengi dengan keteladanan nyata dalam kehidupan yang dilihat sehari-hari oleh siswa. Karenanya, menjadi urgen pula bagi setiap pendidik dan -bahkan setiap muslimyang peduli akan nasib pendidikan umat dan bangsa untuk memahami kekuatan metode kisah dalam pendidikan ini.

Berdasarkan latar belakang masalah diatas, tulisan ini memiliki beberapa tujuan, antara lain :

a. Menjelaskan metode Kisah dalam AlQur'an dan Hadits

b. Mengungkapkan keistimewaan metode Kisah sebagai metode pendidikan

c. Urgensi dan Aplikasi Metode Kisah dalam konteks Pendidikan Karakter Dengan menggunakan metode kualitatif deskriptif, penulis akan menggunakan sumber-sumber utama 
sebagai landasan teori, yaitu Al-qur'an, Hadits-hadits yang shahih, kitab-kitab tafsir, dan buku-buku tentang pendidikan Islam yang ditulis oleh para pakar dan akademisi pendidikan Islam. Selain itu, penulis juga akan mengaitkan dengan pengalaman empiric dalam kaitan metode kisah dalam pendidikan ini, baik yang dialami penulis sendiri maupun pengalaman dan hasil-hasil penelitian. Tentu saja tulisan ini tidak dimaksudkan sebagai hasil penelitian yang matang dan komprehensif, karenanya diskusi dan saran serta masukan sangat diharapkan untuk menghasilkan sesuatu yang bermanfaat terutama untuk pendidikan di Indonesia yang belum juga keluar dari krisis akut-multidimensinya, semoga. Amin

\section{KISAH-KISAH DALAM ALQUR'AN DAN SUNNAH}

\section{Pengertian Kisah}

Dari segi bahasa, terdapat banyak pengertian dalam kata “ قصة “. Kisah bermakna berita juga berarti mengikuti. Menurut al-Azhar, al-Qashas adalah masdar قصيقص yang bermakna mengisahkan. Sedangkan menurut al-Laits, al-Qashas berarti mengikuti jejak. Maka dikatakan خرج فلان قصصا فى اثر فلان, yang artinya, "si Fulan mengikuti jejak si fulan". Ini berarti si Fulan itu mengikuti jejak sahabatnya bisa berarti pula si Fulan memberitakan satu berita kepada orang lain. ${ }^{5}$

Dalam Tafsirnya, Tafsir al-Kabir Wa Mafatih al-Ghaib, Imam Ar-Razi menjelaskan makna Qhashas berdasarkan Q.S. Yusuf (12) : 3, yaitu bahwa makna alQashas adalah yang berarti Khabar atau berita pada dasarnya secara bahasa adalah masdar dari fi'il Qasha Yaqushu Qashahan yang berarti mengikuti. Ar-Razi kemudian mengutip Al-Qur'an surat Al-Qashas (28) : 11:

\footnotetext{
5 Ibn Manzhur, Lisan al-Arab (Qahirah: Dar alMishriyah, 1992) Juz 7, h. 345
}

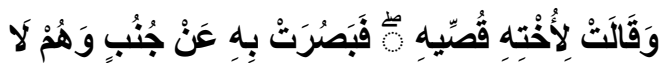

يَشْنْرُونَ

"Dan berkatalah ibu Musa kepada saudara Musa yang perempuan: "Ikutilah dia" Maka kelihatanlah olehnya Musa dari jauh, sedang mereka tidak mengetahuinya".

Maksud dari kalimat "Qushiyhi", yaitu "ikutilah jejak dia". Kemudian Ar-Razi mengutip Surat al-Kahfi (18) ayat 64 :

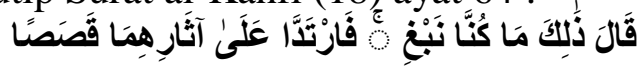

"Musa berkata: "Itulah (tempat) yang kita cari". lalu keduanya kembali, mengikuti jejak mereka semula".

Jadi makna kata Qashahan adalah mengikuti. Maka al-Qashas atau Kisah disebut juga dengan hikayat atau cerita, karena orang yang mengisahkan suatu perkataan itu selalu menyebutkannya sedikit demi sedikit. ${ }^{6}$

Dari pengertian bahasa ini kita dapat menyimpulkan bahwa kisah memang memiliki tujuan dan nilai pendidikan karena ia menuntut untuk diikuti, dijadikan contoh dan panutan. Sesuatu dikisahkan karena diharapkan nilai-nilai kebaikan yang terkandung di dalamnya dapat diikuti.

Secara istilah Kisah didefinisikan oleh Mustafa Muhammad Sulaiman sebagai suatu kepercayaan atas kebenaran sebuah sejarah yang jauh dari kebohongan atau khayalan. ${ }^{7}$ Pengertian ini berbeda dengan istilah Kisah dalam bahasa Indonesia. Dalam kamus bahasa Indonesia disebutkan misalnya, Kisah adalah "wacana yang bersifat cerita baik berdasarkan pengamatan maupun berdasarkan rekaan". Pengertian kedua ini seakan tidak membedakan kisah dengan dongeng. Jadi Qashashul Qur`an adalah berita tentang keadaan umat-umat yang telah berlalu, nubuwat terdahulu dan

\footnotetext{
${ }^{6}$ Imam Muhammad Razi Fakhruddin, Tafsir alKabir Wa Mafatih al-Ghaib, Jilid 18, Beirut, Dar alFikr, 1981, h. 87

${ }^{7}$ Mustafa Muhammad Sulaiman, Al-Qashas fi AlQur'an al-Karim, Qahirah, Mathba'ah Amanah, 1994, cet. 1 h. 16

8 Kamus Besar Bahasa Indonesia, Edisi Ketiga, Jakarta, Balai Pustaka, 2007, h. 572
} 
berbagai peristiwa yang telah terjadi. Sedangkan menurut istilah, artinya menceritakan berita tentang kejadiankejadian yang mempunyai beberapa tahapan, di mana sebagiannya mengikuti yang lain. ${ }^{9}$

Fokus kajian dalam tulisan ini berangkat dari pengertian Kisah berdasarkan Al-Qur'an dan Sunnah, maka tentu pengertian kisah dalam bahasa Indonesia adalah tidak tepat, karena AlQur'an dan Sunnah Shahihah tentu tidak menoleransi berita yang mengandung kebohongan sekecil apapun.

Sayyid Quthb menjelaskan lebih jauh tentang hal ini dalam bukunya, Tashwir alFanni fi al-Qur'an, bahwa kisah dalam AlQur'an bukanlah karya seni yang terpisah, baik dalam subyek, metode penyajian, dan pengaturan kejadian-kejadiannya, seperti yang terdapat pada kisah seni bebas yang bertujuan menunaikan penyajian seninya tanpa ikatan tujuan. Kisah adalah salah satu sarana Al-Qur'an diantara banyak sarananya yang mempunyai berbagai tujuan keagamaan. Al-Qur'an adalah kitab dakwah sebelum segala sesuatunya. Maka kisah adalah merupakan salah satu sarana alQur'an untuk menyampaikan dakwah ini dan mengokohkannya. Kedudukan kisah dalam hal ini sama dengan gambarangambaran yang disajikan tentang hari kiamat, nikmat surga dan azab neraka. Sama dengan bukti-bukti yang diketengahkannya tentang hari berbangkit, untuk menunjukan kekuasaan Allah. Juga sama dengan syariat-syariat yang dirincinya serta tamsil-tamsil yang dibuatnya, dan tema-tema lain yang disebutkan dalam AlQur'an. Kisah dalam al-Qur'an baik temanya, metode penyajiannya, hingga pengaturan-pengaturan kejadiannya tunduk kepada tuntutan tujuan-tujuan agama. Pengaruh dari ketundukan ini terlihat menonjol melalui ciri-ciri tertentu. Meski begitu, ketundukan total kepada tujuan agama ini tidak menghalangi keberadaan

\footnotetext{
${ }^{9}$ Muhammad bin Shalih Al-'Utsaimin, Ushul AtTafsir, dikutip dalam Abu Muhamad Harits, Majalah AsySyari'ah edisi 40
}

karakteristik seni dalam penyajiannya, terutama keistimewaan al-Qur'an yang terbesar dalam menyampaikan ungkapan, yaitu tashwir atau gambaran. ${ }^{10}$

\section{Kisah-kisah Tarbiyah Dalam Al- Qur'an}

Kisah-kisah dalam Al-Qur'an tertuang dalam banyak surat dan meliputi berbagai macam kisah. Dalam bukunya, Rangkaian Cerita Dalam Al-Qur'an, yang telah menjadi klasik dan dicetak berkali-kali sejak pertama kali diterbitkan tahun 1952, Almarhum Bey Arifin melampirkan ayatayat yang dijadikan sandaran dalam menuliskan cerita-cerita dalam Al-Qur'an, antara lain yaitu :

1. Kisah Nabi Adam As : Q.S Al-Baqarah : 29 s.d 30, Al-A'raf : 11-12, Thaha : 116-117, al-Isra : 61-65, al-Hijr : 2843, Shad : 71-75, Fushilat : 9-12, alMaidah : 31-35

2. Nabi Nuh As : Q.S. Ali Imran : 33, AnNisa : 163, al-An-am : 84, al-A'raf : 59-64, Yunus : 71-73, Hud :25-49, AlAnbiya : 76-77, al-Furqan : 38 , asSyu'ara : 105-122, al-Ankabut : 14-15, As-Shaffat : 71-83, Nuh : 1-28, alQamar : 9-16, al-Mukminun : 23-31, al-Mukmin : 5-6.

3. Nabi Hud As : Q.S. Al-A'raf : 65-72, Hud : 50-60, As-Syu'ara : 123-140

4. Nabi Shaleh As ; Q.s. Hud : 61-68, Ala'raf :73-79, Asy-syuara :141-159, Annaml: 45-53, Al-qamar : 23-31, Asysyam :11-15

5. Nabi Ibrahim As : Q.S. Al-Baqarah :260, Az-Zukhruf :26-28, Al-An'am :74, At-Taubah : 114, Maryam :41-48, Al-Anbiya :52-76, Asy-syu'ara :69102, Ash-shaffat :90-97, Al-baqarah :258, Al-An'am :76-83.

6. Nabi Ismail As : Q.S Ibahim : 37-38, Ash-shaffat : 102-113, Al-Baqarah : 125-129, Al-Hajj : 26, Ali Imran : 96, Ibrahim : 35-37

10 Sayyid Quthb, Keindahan Al-Qur'an Yang Menakjubkan, Jakarta, Rabbani Press, 2004, cet ke1, h. 275-276. 
7. Nabi Luth As : Q.S Al 'araf : 80-84, An-Naml : 54-58, Hud : 77-83, AlAnkabut :26-35, Asy-Syu'ara : 160175, Al-Hijr : 57-77, Ash-Shaffat ; 133-138, Al-an'am : 86 Al-Anbiya : 74-75, Al-Hajj : 43-44, Qaf : 13-14, AlQamar : 33-39

8. Nabi Ya'qub As : Q.S Yusuf dan kitabkitab Tarikh dan tafsir

9. Nabi Yusuf As : Q.S Yusuf : 3-104, AlMukmin : 34

10. Nabi Syu'aib As : Q.S Al-'araf : 75-93, Hud : 84-95, Asy-Syu'ara : 176-191, Al-baqarah : 67-83, Al-Ankabut : 3637.

11. Kisah-kisah Nabi-nabi yang lain seperti Nabi Musa as, Nabi Musa dan Khidir, Nabi Daud as, Nabi Sulayman as, Nabi Uzair as, Nabi Ayyub as, Nabi Yunus as, Nabi Zakaria as dan Yahya as, Nabi Isa as, dan Nabi Muhamad SAW.

12. Kisah-kisah lain seperti cerita Qarun, Thalut, Maryam, Zulqarnain, Ashabul Kahfi, Ashabul Ukhdud dan lain-lain. ${ }^{11}$

Adalah menarik bahwa sebuah kisahkisah dalam Al-Qur'an tertulis di beberapa surat bukan dalam satu surat khusus seperti kita lihat dari paparan diatas. Menjawab persoalan ini para ulama telah menjawabnya bahwa pengulangan tersebut justru mengandung nilai kemukjizatan alQur'an, karena sehebat apapun seorang penulis jika diminta menuliskan tema dan kisah yang sama dengan bahasa yang berbeda tanpa sedikitpun mengurangi isinya adalah sesuatu yang sulit. Selain itu, pengulangan juga memiliki tujuan agar pelajaran kisah tersebut melekat kuat dalam benak pendengar atau pembacanya. Contoh keunikan dan i'jaz kisah Al-Qur'an ini dibahas secara lebih detail oleh Abdullah Nasih Ulwan ketika membandingkan Kisah Nabi Musa As yang tertera dalam Surah al-

\footnotetext{
${ }^{11}$ Lebih jauh rincian kisah dan surat dan ayat yang menjelaskannya lihat Bey Arifin, Rangkaian Cerita Dalam Al-Qur'an, Bandung, PT. Al-Maarif, Cet. Ke-7, 1971, h. 504-506
}

A'raf ayat 104-107 dengan Surah AnNazi'at. $^{12}$

Para ulama telah mengklasifikasikan jenis-jenis kisah yang terdapat dalam banyak ayat Al-Qur'an menjadi beberapa Jenis, yaitu :

1. Kisah-kisah para Nabi. Kisah para Nabi Alahimussalam mengandung dakwah kepada kaumnya, mukjizat-mukjizat yang memperkuat dakwah, sikap orangorang yang memusuhinya, tahapantahapan dakwah dan perkembangannya serta akibat-akibat yang diterima oleh mereka yang mempercayai, dan golongan yang mendustakan. Misalnya kisah Nabi Nuh As, Ibrahim As, Musa As, Harun As, Isa As, Muhamad SAW dan lainnya.

2. Kisah-kisah yang berhubungan dengan peristiwa-peristiwa yang terjadi pada masa lalu dan orang-orang selain para Nabi. Misalnya kisah orang yang keluar dari kampung halaman yang banyak jumlahnya karena takut mati, kisah Thalut dan Jalut, dua orang putra Adam As, Ashab al_kahf, Dzulqarnain, Qarun, Ashab al-Sabt, Maryam, Ashab alUkhdud, Ashab al-Fil, dan lain-lain.

3. Kisah-kisah yang berhubungan dengan peristiwa-peristiwa yang terjadi pada masa Rasulullah SAW, seperti perang Badr dan perang Uhud dalam surah Ali Imran, perang Hunain dan Tabuk dalam surah at-Taubah, perang Ahzab dalam surah al-Ahzab, tentang Hijrah, dan peristiwa Isra dan lain-lain. ${ }^{13}$

4. Kisah-kisah Ghaib, yaitu kisah yang mengandung peristiwa dan kejadian yang tidak bisa diketahui oleh manusia tetapi hanya Allah SWT yang mengetahuinya.Yaitu seperti kisah perkara Nabi Isa As, seperti yang

\footnotetext{
12 Abdullah Nasih Ulwan, Tarbiya al-Aulad Fi alIslam, Qahirah, Dar As-Salam, Cet. Ke-21, 1992,Jilid 2, h.661-663.

${ }^{13}$ Dr. Sa'id Ismail Ali, Al-Qur'an Al-Karim ; Ru'yah Tarbawiyah, Qahirah, Dar al-Fikr al-Araby, 2000, h. 307, lihat juga Manna Al-Qattan, Mabahits Fi Ulum al-Qur'an, h. 436
} 
dijelaskan dalam al-Qur'an Surah alMaiidah ayat 116-119. ${ }^{14}$

Kesemua rangkaian kisah-kisah dalam Al-Qur'an mengandung nilai-nilai tarbiyah dalam pengertian yang sesungguhnya. Bahkan satu kisah mengandung sangat banyak pelajaran yang bisa disampaikan seorang pendidik ataupun orang tua kepada anak didiknya. Kisah Qarun misalnya, dengan model pembelajaran tematik bisa dijadikan pembelajaran tentang kemuliaan sikap dermawan dan tercelanya sifat kikir, ini dari aspek Aqidah. Dari aspek sosial juga anak bisa diajarkan pentingnya memelihara sikap empati dan peduli kepada orang lain. Dari aspek ekonomi siswa bisa diajarkan bagaimana seharusnya sikap yang benar dalam berhemat dan menghindari sifat kikir di satu sisi dan sifat boros di sisi yang lain. Dari aspek sejarah sudah tentu menjadi pelajaran berharga tentang diabadikannya kisah orang yang melampaui batas.

Demikian pula kisah-kisah lain yang sungguh merupakan perbendaharaan berharga bagi setiap muslim -dan para pendidik khususnya- untuk dijadikan sebagai pelajaran dan pembelajaran bagi diri, keluarga dan masyarakat. Maka benarlah ungkapan Al-Qur'an dalam Surat Yusuf ayat 111 :

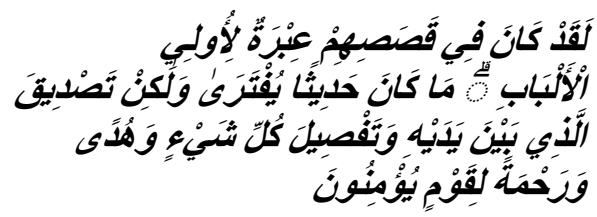

"Sesungguhnya pada kisah-kisah mereka itu terdapat pengajaran bagi orang-orang yang mempunyai akal. Al Quran itu bukanlah cerita yang dibuatbuat, akan tetapi membenarkan (kitabkitab) yang sebelumnya dan menjelaskan segala sesuatu, dan sebagai petunjuk dan rahmat bagi kaum yang beriman".

Ketika menafsirkan ayat ini, Ahmad Mustafa Al-Maraghi menjelaskan bahwa

\footnotetext{
${ }^{14}$ Ibid, 307
}

Kisah Nabi Yusuf as beserta bapak dan saudaranya, adalah pelajaran amat berharga bagi orang-orang yang memiliki akal yang sehat dan berfikir, apa yang dialami Yusuf as beserta bapak dan saudaranya adalah contoh bagaimana akibat perbuatan baik dan buruk, namun bagi orang-orang yang lalai menggunakan akal fikirannya, maka kisah yang luar biasa ini tidaklah berfaedah sama sekali. ${ }^{15}$

Nilai pelajaran yang bisa diambil dari kisah ini, demikian Al-Maraghi melanjutkan penjelasannya, bahwa Zat yang telah mampu menyelamatkan Yusuf as dari dalam sumur, mengangkat derajatnya setelah terpuruk di dalam penjara, menjadikannya raja setelah sebelumnya menjadi budak yang diperjual belikan dengan harga yang murah, mendudukannya sebagai orang mulia setelah terusir terbuang bertahun-tahun lamanya, menyelamatkannya dari maksud jahat saudara-saudaranya, mengumpulkannya kembali dengan ayah tercintanya setelah derita perpisahan panjang yang memilukan, dan mendatangi saudara-saudaranya dengan penuh kasih sayang tanpa rasa dendam, sesungguhnya Zat yang telah mampu melakukan ini pasti jugalah sangat mampu mengangkat dan memuliakan Nabi Muhamad SAW, meninggikan agama Islam ini, menunjukan kemenangannya dihadapan kalian (musuhmusuh Islam), menjadikannya pemenang di muka bumi dengan bala tentaranya yang kuat, dengan pengikut dan penolongpenolongnya, meskipun telah banyak kesulitan dan penderitaan yang telah dialami. $^{16}$

\section{Tujuan Kisah Dalam Al-Qur'an}

Kisah-kisah dalam Al-Qur'an memiliki tujuan yang sangat penting yaitu : 1. Kisah-kisah dapat membuktikan kummi-an Nabi Muhamad SAW, karena

\footnotetext{
${ }^{15}$ Ahmad Mustafa Al-Maraghi, Tafsir Al-Maraghi, Jilid.13, Mesir, Mustafa Bab al-Halaby, cet ke-1, 1946, h. 56

${ }^{16}$ Ahmad Mustafa Al-Maraghi, Tafsir Al-Maraghi, h. 57
} 
kisah-kisah yang diceritakan beliau memperlihatkan datang dari Allah SWT.

2. Bahwa seluruh agama yang dibawa para Nabi berasal dari Allah, satu risalah yang diturunkan mulai dari Nabi Adam hingga Nabi Muhamad SAW

3. Melalui model kisah-kisah, maka akan lahir keyakinan, bahwa Allah SWT akan selalu menolong Rasul-Nya dan kaum mukmin dari segala kesulitan dan penderitaan. Dengan kata lain, Allah SWT tidak akan membiarkan orangorang yang beriman jatuh dalam kesusahan dan keterpurukan.

4. Dengan model kisah dapat dilihat bahwa musuh abadi manusia adalah iblis atau setan yang selalu ingin menjerumuskan manusia. Sekaligus model kisah dapat memupuk iman. ${ }^{17}$

\section{Kisah-kisah Tarbiyah Dalam Sunnah}

Sebelum lebih jauh mengkaji kisah-kisah Tarbiyah dalam Sunnah, penulis ingin memperjelas makna kata Sunnah yang digunakan dalam konteks makalah ini dengan mengutip Musthafa As-Siba'i dalam bukunya As-Sunnah Wa Makanatuha Fi at-Tasriy alIslamy. Pengertian Sunnah yang digunakan dalam tulisan ini adalah definisi sunnah menurut Muhaddisin, yaitu :

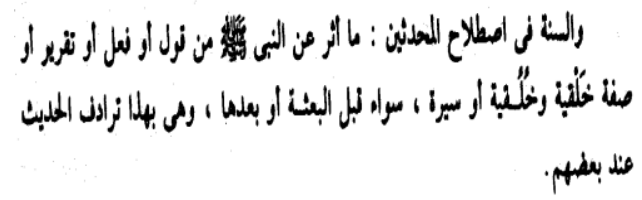

Jadi yang dimaksud Sunnah disini sangatlah luas dan mencakup seperti yang digambarkan dalam definisi diatas. Dan membedakannya dengan definisi yang diberikan Ushuliyin yang mendefiniskan sunnah sebagai : Apapun yang disampaikan dari Nabi Muhamad SAW baik berupa perkataan, perbuatan maupun takrir. ${ }^{18}$

17 Dr. Ulil Amri Syafri, Pendidikan Karakter Berbasis Al-Qur'an, Jakarta, Rajawali Press, 2012, h. 125

${ }^{18}$ Musthafa As-Siba'i, As-Sunnah Wa Makanatuha Fi at-Tasriy al-Islamy, Beirut, Al-Maktab al-Islamy, 1982, h. 47, dikutip dalam Dr. Sa'id Ismail Ali, AsSunah An-Nabawiyah ; Ru'yah Tarbawiyah, Qahirah, Dar al-Fikr Al-Araby, 2002, h. 29.
Pembahasan hubungan Sunnah dengan Tarbiyah adalah pembahasan yang amat luas, dalam kajian ini penulis hanya ini menyinggung sedikit saja tentang metode kisah yang digunakan Rasulullah SAW yang memiliki pengaruh yang kuat terhadap penanaman nilai-nilai Islam kepada para Sahabat.

Rasulullah SAW adalah orang yang pertama kali menggunakan metode kisah dalam pendidikan dan dakwah kepada umatnya. Ini adalah kesimpulan dan fakta yang tak terbantahkan yang disampaikan oleh Ibn Jarir At-Thabari. ${ }^{19}$ Hal ini karena Al-Qur'an yang diturunkan kepada beliau memang membawa banyak kisah-kisah umat-umat terdahulu seperti telah diuraikan pada paparan sebelumnya. Dengan metode kisah inilah Nabi Muhamad SAW menanamkan nilai-nilai keimanan ke dalam dada para sahabat. Terkadang Rasul SAW meminta sahabat mendengarkan kisah yang akan disampaikannya, terkadang juga kaum musyrikin meminta Rasul SAW mengisahkan tentang umat terdahulu dengan tujuan menguji kebenaran risalah yang dibawanya. Dengan cara inilah seringakali Rasulullah SAW menyampaikan kisah-kisah baik yang terdapat didalam Al-Qur'an maupun berdasarkan wahyu yang Allah SWT sampaikan. $^{20}$

Dengan kisah-kisah inilah banyak kaum ahli kitab yang akhirnya mengakui kebenaran risalah agama Islam seperti yang terjadi pada peristiwa dialog raja Najasyi dengan Ja'far Ibn Abi Thalib pada peristiwa hijrah ke Habasyah. Ketika Rasul Saw menyampaikan sebuah kisah maka para sahabat dengan penuh antusias mendengarkannya. Bahkan mereka dengan senang hati menunggu kapan Nabi yang mulia akan menyampaikan kisah-kisahnya.

\footnotetext{
${ }^{19}$ Abi Ja'far Muhamad ibn Jarir A-Thabari, Jami alBayan fi Ta'wil Ayil Qur'an, Tahqiq Dr. Abdullah bin Abd al-Muhsin At-Turkiy, Qahirah, Hajar, 2001, Jilid 2, h. 191-192

${ }^{20}$ Dr. Sa'id Ismail Ali, As-Sunah An-Nabawiyah ; Ru'yah Tarbawiyah, Qahirah, Dar al-Fikr Al-Araby, 2002, h. 340
} 
Sebuah riwayat dalam Sunan Ad-Darimi, ${ }^{21}$ menjelaskan :

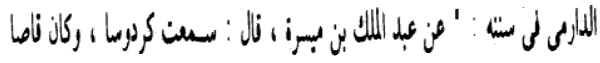

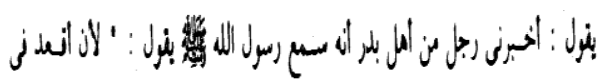

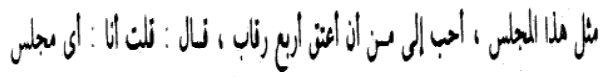

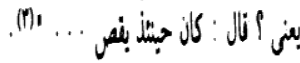

Hadits ini memberikan gambaran bahwa Rasulullah SAW juga senang terhadap kisahkisah.

Demikian pula perhatian Rasulullah SAW yang begitu tinggi terhadap kisah seperti dalam sebuah riwayat yang disebutkan dalam Musnad Imam Ahmad :

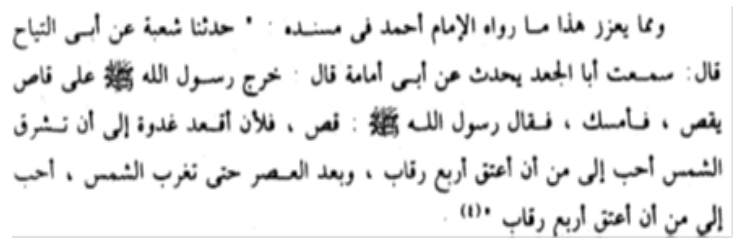

Perhatian yang tinggi terhadap kisah juga terlihat dari seringnya Rasulullah SAW mengulang-ulang satu kisah hingga beberapa kali pada majlis yang berbedabeda. Hal ini dimaksudkan selain karena bagi beberapa sahabat ada yang baru mendengarnya juga agar nilai-nilai pendidikan yang terkandung di dalamnya tertancap kuat. Dan perhatian sahabat untuk tidak terlewatkan dari kisah yang disampaikan Rasulullah SAW dapat kita saksikan dari peristiwa yang terjadi antara Umar Ibn Khatab ra dengan salah seorang sahabatnya dari golongan Anshar.

Suatu ketika keduanya sepakat untuk berangkat melakukan aktifitasnya, salah seorang diantaranya akan pergi menuju majlis Rasulullah SAW dan seorang lagi menuju ke tempatnya bekerja, ketika keduanya bertemu maka yang mengikuti majlis Rasulullah SAW menyampaikan kisah-kisah yang ia dengar dari Rasulullah

21 Sunan Ad-Darimi, Al-Qahirah, Syirkah alThaba'ah Al-Fanniyah al-Muttahidah, 1959, J.2, h. 227. Dikutip dalam As-Sunnah An-Nabawiyah, h. 346
SAW kepada saudaranya yang tidak bisa menghadiri majlisnya. ${ }^{22}$

Kisah-kisah yang Rasulullah SAW sampaikan memiliki nilai bahasa dan sastra yang amat tinggi selain tentu nilai tarbiyah bagi jiwa. Kisah-kisah seperti tiga orang yang terjebak di dalam goa misalnya, adalah sebuah kisah yang sangat indah tentang kebaikan, kejujuran dan keikhlasan. Demikian pula kisah-kisah lain seperti Kisah Alqamah, kisah Tsa'labah, dan kisahkisah lain yang saat ini sudah banyak diterbitkan dengan cover dan perwajahan yang menarik. Kisah-kisah ini menjadi bahan yang sangat berharga bagi para orang tua dan pendidik dalam menanamkan nilainilai karakter kepada anak dan muridnya.

\section{Tujuan Kisah Dalam Sunnah}

Kisah-kisah yang terdapat dalam Sunnah memiliki tujuan yang bisa diringkas sebagai berikut :

a. Kisah menjadi media pembelajaran dalam menyampaikan ilmu kepada para sahabat.

b. Kisah menjadi sumber ilmu itu sendiri, karena banyak hal yang baru sahabat ketahui dari kisah yang disampaikan

c. Kisah menjadi media dalam menyampaikan dakwah karena sebagaimana telah jelaskan bahwa sudah menjadi fitrah bahwa manusia menyenangi kisah

d. Kisah digunakan untuk menjelaskan AlQur'an dan isi kandungannya

e. Kisah dijadikan media menancapkan nilai-nilai akhlak mulia

f. Kisah juga menjadi sumber motivasi bagi kaum muslimin dalam menghadapi para musuh Islam, seperti kisah Nabi Musa As dan kaumnya berhadapan dengan Fir'aun dan bala tentaranya, telah memberikan kekuatan kepada kaum muslimin bahwa kebenaran pasti akan menang dan dimenangkan Allah

\footnotetext{
${ }^{22}$ Shahih Al-Bukhari, Jilid 1, h. 33, dikutip dalam . Dr. Sa'id Ismail Ali, As-Sunah An-Nabawiyah ; Ru'yah Tarbawiyah, Qahirah, Dar al-Fikr Al-Araby, 2002, h. 347
} 
SWT meskipun jumlah dan kekuatan musuh lebih besar dan kuat. ${ }^{23}$

\section{B. PEMBAHASAN}

\section{Peran dan Kekuatan Kisah}

Pada tahun 1794, seorang anak lelaki kecil menjalani operasi untuk mengangkat tumor yang dideritanya. Bayangkan, seorang anak kecil berusia sembilan tahun menghadapi kilauan pisau bedah lebih dari 200 tahun yang lalu. Antibiotik belum lagi ditemukan. Louis Pasteur belum lagi menerangi dunia medis dengan pentingnya sterilisasi. Anestetis kimia untuk mengontrol rasa sakit baru ditemukan satu abad kemudian. Yang bisa ditawarkan pada anak tersebut hanyalah sebuah cerita. Untuk membantu mengalihkan perhatiannya dari prosedur pembedahan, dia didongengi sebuah cerita yang amat memikat sehingga sesudah operasi dia mengaku tidak merasakan rasa sakit sedikitpun. Delapan belas tahun kemudian anak yang sama menyerahkan salah satu cerita karangannya sendiri kepada sebuah penerbit. Namanya adalah Jacob Grimm. Apa judul cerita tersebut ? Putri Salju. Sesudah itu dia menjadi salah satu pembawa cerita dongeng paling masyhur di dunia. ${ }^{24}$

Bandung tahun 2008, Rico adalah seorang remaja keras kepala pecandu narkoba yang terbengkalai studinya. Saat teman-temannya sudah wisuda, ia masih juga malas menggarap skripsinya. Suatu ketika orang tuanya mendapatinya menangis di kamarnya. Kosasih dan Winarti, orang tua Nico penasaran, ternyata anaknya sedang membaca buku Laskar Pelangi. Mendadak setelah itu Nico

${ }^{23}$ Dr. Sa'id Ismail Ali, As-Sunah An-Nabawiyah ; Ru'yah Tarbawiyah, Qahirah, Dar al-Fikr Al-Araby, 2002, h. 347-348

24 George W. Burns, 101 Kisah Yang Memberdayakan ; Penggunaan Metafora Sebagai Media Penyembuhan, Bandung, Mizan, 2004, h. $43-$ 44 menyatakan tekadnya untuk menyelesaikan rehab ketergantungan obat. Padahal rehab itu berkali-kali gagal hingga orang tuanya nyaris putus asa. Nico juga mulai mau mengerjakan skripsinya. Kisah dalam buku Laskar Pelangi, yang semula adalah memoar masa kecil Andrea Hirata tentang guru-guru dan teman kecilnya, telah membangkitkan semangat dan merubah hidupnya. Kisah ini diceritakan Winarti pada program Kick Andy di Metro TV. ${ }^{25}$

Kekuatan sebuah kisah atau cerita sudah sering diungkapkan orang. Bahkan jika anak-anak kita diminta untuk menuliskan sebuah cerita misalnya, akan kita temukan kebanyakan -bahkan mungkin semuanya- akan menuliskan penggalan awal kalimatnya dengan kalimat "Pada suatu hari....." atau "Pada zaman dahulu kala....".Secara tidak sadar, anak-anak akan mengungkapkan apa yang pernah dan sering mereka dengar dari kisah-kisah yang dibacakan bundanya di malam-malam sebelum tidur di masa kecil. Kisah-kisah ini, ujar George W. Burns, seorang ahli psikoterapi, mulai membentuk kehidupan kita, dan cerita-cerita yang mulai kita ceritakan, pada gilirannya, menahbiskan siapa diri kita sebenarnya. ${ }^{26}$

Bandingkan, kata Dr. Said Ismail Ali ketika membahas kekuatan sebuah kisah, mana yang lebih banyak orang-orang yang menghadiri seminar-seminar, diskusi dan simposium dengan yang mendatangi gedung-gedung bioskop untuk menonton film atau pertunjukan teater. Karena kisah adalah unsur intrinsik yang ada pada manusia dan setua peradaban manusia, maka bukanlah hal yang aneh jika manusia senang dengan kisah dan cerita. ${ }^{27}$

Buku-buku yang menjadi best seller dan terjual jutaan copi seringkali adalah

\footnotetext{
25 Asrori S. Karni, Laskar Pelangi :The Phenomenon, Bandung, Hikmah-Mizan, 2008, h. 2

26 George W. Burns, 101 Kisah Yang Memberdayakan ; Penggunaan Metafora Sebagai Media Penyembuhan, Bandung, Mizan, 2004, h. 27

${ }^{27}$ Dr. Sa'id Ismail Ali, As-Sunah An-Nabawiyah ; Ru'yah Tarbawiyah, Qahirah, Dar al-Fikr Al-Araby, 2002, h.
} 
buku-buku kisah dan cerita, baik kisah nyata maupun fiktif. Bahkan, buku Chicken Souf of The Soul yang begitu laris dan diterjemahkan ke berbagai bahasa adalah kumpulan kisah dan cerita nyata yang dikirim kepada penulisnya yang kemudian dipilah-pilih sesuai dengan tema yang dibuat penulisnya.

Pada banyak peradaban kita temukan bahwa kisah telah menjadi sebuah metode pewarisan nilai-nilai kebijakan dan kebajikan. Di Negeri Tibet yang terletak di daerah tinggi tak berangin di sisi pegunungan Himalaya, seni bercerita menjadi sarana untuk mengkomunikasikan kebijakan religius, juga sekalgus sarana hiburan rekreasional utrama. Dengan cara inilah mereka menceritakan sejaraha negeri mereka dan nilai-nilai kemasyarakatan kepada generasi yang lebih muda. Di samping para pembaca kisah dan cerita tradisioanl, para penutur kisah profesional di Tibet yang disebut Lama mani ditawari hadiah berupa makanan sebagai ganti cerita yang mereka bawakan. Mereka inilah yang menceritakan legenda kepahlawanan tentang perang dan keberanian di samping cerita-cerita lain yang membangkitkan emosi. Norbu Chophel (1983), yang sudah mencoba memelihara beberapa cerita rakyat dari Tibet, mengatakan bahwa orang-orang bersedia duduk selama berjam-jam untuk mendengarkan seorang Lama mani, menyeka air mata, lalu tanpa merasa malu pulang dengan mata merah. ${ }^{28}$

\section{Kekuatan Dan Keistimewaan Kisah- kisah dalam Al-Qur'an}

Paparan diatas memberikan kita sebuah kesimpulan tentang eratnya kaitan antara kisah dan manusia serta kehidupannya. Kisah dan manusia adalah dua hal yang tidak terpisahkan. Manusia membutuhkan kisah-kisah, dan kisah-kisah tentang manusia disebarkan lagi kepada manusia

28 George W. Burns, 101 Kisah Yang Memberdayakan ; Penggunaan Metafora Sebagai Media Penyembuhan, Bandung, Mizan, 2004, h. 47 baik dengan taradisi bertutur lisan, tulisan, maupun dengan gambar dan pentas-pentas.

Dan kisah-kisah terbaik, tentulah kisahkisah yang ditulis oleh pencipta manusia itu sendiri, Allah SWT. Itulah kisah-kisah yang tertera dalam Al-Qur'an yang kebenarannya tidak sedikitpun menyisakan keraguan.

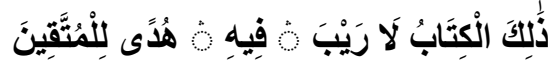
"Kitab (Al Quran) ini tidak ada keraguan padanya; petunjuk bagi mereka yang bertaqwa". (Al-Baqarah (2) : 2)

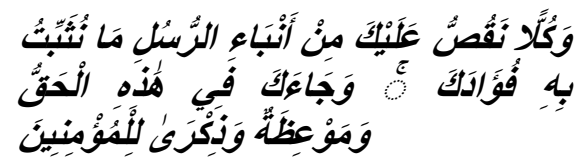

"Dan semua kisah dari Rasulrasul Kami ceritakan kepadamu, ialah kisah-kisah yang dengannya Kami teguhkan hatimu; dan dalam surat ini telah datang kepadamu kebenaran serta pengajaran dan peringatan bagi orang-orang yang beriman." (Q.S. Hud : 120)

Kisah-kisah dalam Al-Qur'an memiliki kelebihan dan keistimewaan yang tidak dimiliki oleh kisah manapun di dunia ini. Al-Qur'an bukanlah kitab kisah atau apalagi sekedar buku dongeng atau kumpulan cerita. Tetapi, Al-Qur'an tentu sangat memahami akan kecenderungan manusia menyenangi kisah-kisah. Sejumlah keistimewaan kisah-kisah dalam Al-Qur'an telah banyak dijelaskan oleh para ulama, antara lain yang dipaparkan oleh Abdrurrahman An-Nahlawi, yaitu :

1. Kebenaran dan kesahihan kisah yang terdapat di dalamnya. Hal ini yang membedakannya dengan kisah-kisah lain yang bercampur dengan dongengdongeng dan fantasi belaka

2. Kesesuaiannya dengan fitrah manusia dan menjadi solusi bagi masalahmasalah yang dihadapi. 
3. Mendidik jiwa dan kecenderungan manusia pada kebaikan

4. Kisah-kisah Al-Qur'an mengandung nilai-nilai kebenaran agama Islam, seperti kebenaran wahyu dan risalah agama Islam (Q.S. Yusuf : 3) dan (Q.S. Hud : 49).

5. Kisah-kisah dalam Al-Qur'an dapat berdialog dan menjawab logika-logika manusia secara ilmiah karena kisahkisah tersebut melibatkan akal manusia untuk selalu berfikir. $^{29}$

\section{Metode Kisah Dan Pendidikan Karakter}

a. Problem Pendidikan Karakter

Pendidikan karakter adalah pendidikan nilai, pendidikan budi pekerti, pendidikan moral, pendidikan watak yang bertujuan mengembangkan kemampuan peserta didik untuk memberikan keputusan baik-buruk, memelihara apa yang baik dan mewujudkan kebaikan itu dalam kehidupan sehari-hari dengan sepenuh hati. Demikian definis pendidikan karakter dalam Rencana Aksi Nasional Pendidikan Karakter Departemen Pendidikan Dan Kebudayaan Republik Indonesia tahun 2010.

Terdapat 18 nilai-nilai karakter dalam naskah akademik Pengembangan Pendidikan Budaya dan Karakter Baangsa, Kementerian Pendidikan Nasional yaitu : Religius, Jujur, Toleransi, Disiplin, Kerja keras, Kreatif, Mandiri, Demokratis, Rasa ingin tahu, Semangat kebangsaan, Cinta tanah air, Menghargai prestasi, Bersahabat dan komunikatif, Cinta damai, Gemar membaca, Peduli lingkungan, Peduli sosial dan Tanggung jawab. ${ }^{30}$

\footnotetext{
${ }^{29}$ Abdurrahman An-Nahlawi, Ushul at-Tarbiyah alIslamiyah wa Asalibuha, Damaskus, Dar al-Fikr, 2003, h. 390-392.

30 Dr. Ulil Amri Syafri, Pendidikan Karakter Berbasis Al-Qur'an, Jakarta, Rajawali Press, 2012, h. xi-xiii
}

Melihat ke delapan belas karakter yang ditargetkan dalam Kurikulum Pendidikan Nasional memang sangatlah ideal, dan demikianlah seharusnya memang lulusan sekolah yang kita harapkan. Tetapi setelah hampir 3 tahun sejak dicanangkan, belum terlihat hasil yang diharapkan, kecuali berubahnya buku kurikulum yang ada di sekolah. Pada praksisnya, proses pendidikan masih berjalan sebagaimana adanya. Pengecualian mungkin di beberapa sekolah dan lembaga pendidikan yang memang memiliki kesiapan SDM dan finansial yang mencukupi.

Di tengah gencarnya sosialisasi kurikulum berkarakter, wajah pendidikan kita justru disuguhi faktafakta yang justru bertolak belakang dari harapan. Tawuran pelajar yang menjurus kriminalitas, prostistusi dan pergaulan bebas serta pornografi yang sudah nyaris melewati batas kewajaran, narkoba dan lain-lain. Perilaku orangorang dewasa yang juga hasil pendidikan bahkan jauh lebih buruk daripada itu, yang justru dilakukan oleh para pemimpin di hampir semua level, lokal maupun nasional, legislatif, ekeskutif dan yudikatif, semuanya mempertontonkan wajah moral dan kualitas sebuah bangsa. Indikasinya adalah posisi Indonesia yang berada di peringkat bawah dalam hampir semua yang baik, dan berada di peringkat tinggi pada hal-hal yang negatif dan buruk seperti korupsi, pornografi, polusi, kekerasan dan lain-lain. Dan bangsa yang (hampir) gagal tentulah dihasilkan dari sistem pendidikan yang gagal.

Saat kurikulum pendidikan karakter belum lagi tuntas diaplikasikan, dunia pendidikan di Indonesia kembali riuh oleh perampingan kurikulum yang mulai akan diujicobakan pada tahun 2013. Terlepas dari perdebatan dan 
kontroversi tentang hal itu, hemat penulis persoalan mendasar tentang kualitas guru yang merupakan penyampai ilmu belum serius dilakukan.

Hal ini bisa dibuktikan dengan belum dipahaminya hakikat pendidikan karakter oleh kalangan pendidik. Pendidikan karakter lalu dipahami sebagai mata pelajaran tersendiri seperti mata pelajaran PMP atau PKN. Kalaupun ada yang memahaminya sebagai nilai-nilai yang masuk dalam semua mata pelajaran bahkan pada seluruh aktifitas guru, murid dan lingkungan sekolah, masih kesulitan menerapkannya dalam proses pembelajaran. Hal ini ditambah dengan beratnya beban administrative yang kadang lebih menyita waktu guru untuk mempersiapkan mengajar dan menambah ilmu.

Persoalan-persoalan lain yang tak kalah pentingnya bagi peningkatan kualitas pendidikan tentu masih sangat banyak, baik yang berkaitan dengan policy (kebijakan), persoalan birokrasi pendidikan, minimnya sarana dan prasarana yang menunjang dan persoalan-persoalan lain yang masih sangat banyak.

\section{b. Aplikasi Metode Kisah Dalam Pendidikan Karakter}

Berkaca dari fenomena yang menyesakkan itu tentu terlalu simplistis jika penulis mengatakan bahwa metode pendidikan Kisah adalah solusi utamanya. Tetapi dengan beberapa fakta dan landasan teori yang penulis ungkapkan, maka penulis tetap meyakini bahwa pendidikan dengan metode kisah adalah salah satu media yang sangat penting dan dibutuhkan dalam pendidikan karakter anak didik.

Selain dari dalil-dalil naqli dan logika yang telah penulis uraikan, metode kisah juga adalah metode yang sesuai dengan temuan-temuan modern dalam dunia pendidikan saat ini yang telah mengakui pentingnya proses belajar yang seimbang dan terintegrasi antara aktifitas otak kanan dan otak kiri, antara rasio dan emosi. ${ }^{31}$ Demikian pula revolusi makna kecerdasan yang dimulai dengan temuan Daniel Goleman dengan EQ atau kecerdasan emosi, telah menyadarkan banyak pihak bahwa keberhasilan seseorang lebih banyak ditentukan oleh kecerdasan emosi ketimbang IQ nya.

Bahkan ketika sebuah kisah disampaikan dengan cara yang tepat dan suasana yang tepat, maka saat itu bukan hanya kedua belah otak yang sedang bekerja, tetapi juga kalbu dan perasaannya tengah diarahkan mengikuti nilai-nilai yang terkandung di dalamnya. Saat itulah proses transfer ilmu tengah berlangsung, yang bukan hanya melibatkan antara otak pengajar dengan siswanya, tapi juga kalbu guru dengan kalbu muridnya

Jika pembelajaran metode kisah dalam pendidikan karakter adalah sesuatu yang urgen dan niscaya, maka persoalan selanjutnya adalah bagaimana mengaplikasikannya dalam proses pembelajaran.

Dalam kurikulum pendidikan Nasional yang ada selama ini beberapa kisah memang tercantum pada mata pelajaran Agama. Namun sayangnya, dengan durasi waktu yang sangat sedikit tentu tidak memadai untuk menyampaikan muatan pelajaran agama yang sedemikian luas itu.

Pada sekolah-sekolah yang berada di bawah naungan Departemen Agama masih terdapat mata pelajaran Sejarah Kebudayaan Islam. Tetapi sayangnya guruguru mata pelajaran ini, termasuk juga guru sejarah nasional, lebih focus pada hala-hal yang sifatnya factual saja seperti tanggal dan tahun kejadian, tempat dan detail-detail yang kadang justru membuat siswa merasa pelajaran sejarah adalah pelajaran yang sulit dan membosankan. Beberapa lembaga pendidikan Isalam yang sudah maju seperti

31 Dr. Nusa Putra, M.Pd, Metode Penelitian Kualitatif Pendidikan, Jakarta, Rajawali Per, 2012, h. 21 
Sekolah Islam Terpadu telah menjadikan mata pelajarn kisah sebagai mata pelajaran khusus. Hal ini sangat bagus, namun bagi sekolah yang jadual belajarnya tidak full day seperti sekolah terpadu tentu kesulitan menambah mata pelajaran baru.

Karena itula penulis memberikan beberapa saran yang mungkin bisa diterapkan pada sekolah-sekolah yang belum mampu menerapkan model sekolah terpadu yang memang membutuhkan dana yang cukup besar, yaitu antara lain :

1. Mendorong semua guru untuk membaca, memahami, dan menghayati kisah-kisah baik dari Al-qur'an, Sunnah maupun sumber laian yang diakui kebenarannya

2. Menciptakan lingkungan sekolah dan kelas yang "berkisah", yaitu menjadikan kisah-kisah Islami sebagai budaya yang sering dibicarakan dan diungkapkan oleh kepala sekolah maupun guru dalam kesempatankesempatan yang ada

3. Pada setiap pelajaran guru mengupayakan menyisipkan kisahkisah yang disesuaikan dengan kondisi waktu dan keadaan.

4. Melatih kemampuan guru menyampaikan kisah baik dengan lisan maupun tulisan

5. Mengadakan lomba-lomba yang berkaitan dengan kisah, baik itu lomba mendongeng, mewarnai, drama atau teater dan lain-lain.

Adapun materi-materi kisah tentu sudah sangat banyak tersebar, baik yang berasal dari Al-Qur'an, Sunnah, Kisahkisah para Sahabat Rasul SAW, kisah orang-orang saleh, maupun kisah-kisah lain yang melahirkan semangat dan nilai-nilai moral yang tinggi.

Karena itu yang terpenting bukanlah dari mana sumber kisah bisa didapatkan, melainkan kesadaran dan pemahaman guru akan pentingnya kisah-kisah ini sebagai media pembelajaran moral dan karakter. Sudah terlalu banyak anak-anak kita dijejali dengan kisah-kisah sinetron dan tayangan
TV yang merusak cara berpikir dan moral mereka. Karena itulah para guru dan orang tua harus melakukan counter dengan menanamkan nilai-nilai moral sejak dini pada anak-anak kita. Dan media yang paling tepat dan menyenangkan adalah dengan media kisah. Wallahu A'lam Bisshawab

\section{KESIMPULAN}

Metode Kisah adalah salah satu metode pendidikan Islam yang berbasis Al-Qur'an dan Sunnah sebagaimana telah penulis paparkan dalil-dalil naqli mapun aqli yang mendukung pandangan ini. Keberhasilan dalam pendidikan tentu tidak bisa hanya ditentukan oleh satu metode saja. Karena kompleksitas manusia dengan ragam karakter dan kondisi yang melatarbelakanginya, maka dibutuhakn metode yang tepat pada situasi yang tepat pula.

Pendidikan dengan metode kisah memilki peran dan fungsi yang sangat penting, baik sejak kanak-kanak maupun dewasa. Tentu saja karena perbedaan usia maka materi maupun metode penyampaiannya haruslah disesuaikan. Metode kisah pada anak-anak usia PAUD dan TK misalnya, tentu membutuhkan teknik mendongeng yang mampu merebut perhatian dan emosi anak. Hal ini bukan hanya berlaku bagi guru-guru di sekolah tetapi juga pada orang tua.

Pada usia SD dan SMP atau bahkan SMA sekalipun, metode kisah tetap memiliki daya tarik dan daya gugah. Lagilagi guru maupun penutur kisah harus mampu melihat situasi dan kondisi muridmuridnya. Gaya bahasa dan kemampuan mengolah kata akan sangat mempengaruhi emosi dan perhatiannya. Dan yang tidak boleh dilupakan bahwa guru maupun orang tua yang menyampaikan kisah-kisah kebaikan dan keteladanan haruslah sosok yang juga layak diteladani. Karena itulah metode Qudwah atau keteladanan adalah metode awal yang harus dimiliki seorang 
guru jika ingin merubah siswanya menjadi manusia yang berkarakter.

Selain itu penting bagi guru dan orang tua mempelajari teknik-teknik berkisah yang baik yang mampu "menyihir" siswa maupun anak-anaknya dengan kisah-kisah yang disampaikan. Saat ini buku-buku dan informasi tentang teknik bercerita sudah sangat banyak dan mudah didapatkan. Tanpa keteladanan dan kemampuan teknik berkisah yang baik maka kekuatan dan kehebatan metode kisah sebagaimana dibahas dalam makalah ini tentu tidak akan tercapai.

Akhirnya, perlu penelitian lebih lanjut tentang sejauh mana pengaruh kisah-kisah yang diajarkan di rumah maupun di sekolah dan lembaga pendidikan lainnya, terhadap perilaku maupun perjalanan hidup seseorang. Ini tentu butuh kerja keras, waktu dan tenaga, tetapi pastinya bermanfaat untuk menjadi bukti ilmiah tentang betapa pentingnya berkisah kepada anak-anak dan murid kita.

\section{DAFTAR PUSTAKA}

Al-Ghamidy, Abdurrahman bin Abd alKhalik bin Hajar, Madkhal Ila AtTarbiyah Al-Islamiyah, Riyadh, Dar alKhariji, $1418 \mathrm{H}$

Al-Hazimi, Khalid bin Hamid, Ushul AtTarbiyah Al-Islamiyah, Madinah alMunawarah, Dar Alam Lil Kutub, 2000

Ali, Sa'id Ismail, Al-Qur'an Al-Karim ; Ru'yah Tarbawiyah, Qahirah, Dar alFikr al-Araby, 2000

Al-Maraghi, Ahmad Mustafa, Tafsir AlMaraghi, Mesir, Mustafa Bab alHalaby, 1946, cet ke-1 Jilid.13

An-Nahlawi, Abdurrahman, Ushul atTarbiyah al-Islamiyah wa Asalibuha, Damaskus, Daral-Fikr, 2003

Arifin, Bey Rangkaian Cerita Dalam AlQur'an, Bandung, PT. Al-Maarif, Cet. Ke-7, 1971
Ar-Razi, Muhammad Fakhruddin, Tafsir alKabir Wa Mafatih al-Ghaib, Jilid 18, Beirut, Daral-Fikr, 1981

A-Thabari, Abu Ja'far Muhamad ibn Jarir, Jami al-Bayan fi Ta'wil Ayil Qur'an, Tahqiq Dr. Abdullah bin Abd alMuhsin At-Turkiy, Qahirah, Hajar, 2001, Jilid 2

At-Thabari, Abi Ja'far Muhamad ibn Jarir, Jami al-Bayan fi Ta'wil Ayil Qur'an, Tahqiq Dr. At-Turkiy, Abdullah bin Abd al-Muhsin Qahirah, Hajar, Jilid ke-13, 2001

Burns, George W., 101 Kisah Yang Memberdayakan ; Penggunaan Metafora Sebagai Media

Penyembuhan, Bandung, Mizan, 2004

Ibn Manzhur, Lisan al-Arab (Qahirah: Dar al-Mishriyah, 1992) Juz 7

Kamus Besar Bahasa Indonesia, Edisi Ketiga, Jakarta, Balai Pustaka, 2007, h. 740

Karni, Asrori S., Laskar Pelangi :The Phenomenon, Bandung, HikmahMizan, 2008

Musnad Ibn Hanbal, Tahqiq Ahmad Muhamad Syakir, Qahirah, Dar alMa'arif, 1955, Jilid 5

Putra, Nusa, Dr. Metode Penelitian Kualitatif Pendidikan, Jakarta, Rajawali Per, 2012

Quthb, Sayyid, Keindahan Al-Qur'an Yang Menakjubkan, Jakarta, Rabbani Press, cet. $\mathrm{Ke}-1,2004$

Sulaiman, Mustafa Muhammad, Al-Qashas fi Al-Qur'an al-Karim, Qahirah, Mathba'ah Amanah, cet. Ke-1, 1994

Sunan Ad-Darimi, Al-Qahirah, Syirkah alThaba'ah Al-Fanniyah al-Muttahidah, 1959, Jilid 2

Syafri, Ulil Amri, Pendidikan Karakter Berbasis Al-Qur'an, Jakarta, Rajawali Press, 2012

Ulwan, Abdullah Nasih, Tarbiyah al-Aulad Fi al-Islam, Qahirah, Dar As-Salam, 1992, Cet.Ke-21 Jilid 2 